\title{
Life cycle, survivorship and life expectancy of foliage spider (Marpissa bengalensis) in citrus orchard
}

\section{Muhammad Nawab ${ }^{1}$ Mushtaq Hussain Lashari ${ }^{2}$}

\footnotetext{
${ }^{1}$ Department of Zoology, Khawaja Fareed Government Post Graduate College, Rahim Yar Khan, Punjab, Pakistan, 64200.

${ }^{2}$ Department of Life Sciences, The Islamia University of Bahawalpur, Punjab, Pakistan, 63100. E-mail: mushtaqlashary@gmail.com. ${ }^{*}$ Corresponding author.
}

ABSTRACT: The post embryonic developmental stages of Marpissa bengalensis (Araneae; Salticidac), the $2^{\text {nd }}$ most abundant predatory species in citrus orchard were collected from the experimental fruit garden, department of Horticulture, located at the campus of University of Agriculture Faisalabad andstudied. Life cycle was observed in the laboratory, which started from egg sac collected from the field along with gravid female and released into the spider cages. The incubation period ranged from 5-15 days. The average eggs hatched were 23.8 eggs/ cocoon and hatching \% under laboratory conditions was recorded as $73.18 \%$. The average duration of spiderlings span on their mothers back was 7 days. An overall, mean duration of $3^{\text {rd }}$ spiderling stage was of 7.46 days. All spiderlings hatched from 8 cocoons. At the $4^{\text {th }}$ spiderling stage, the average duration was of 10.23 days. In the $5^{\text {th }}$ spiderling stage, the spiderling spent an average of 19.82 days. The $6^{\text {th }}$ and $7^{\text {th }}$ spiderlings stages lasted a total of 23.14 days and 25.86 days respectively. During $8^{\text {th }}$ spiderling stage, the duration was maximum and it was recorded in 28.08 days. On average, from hatching to adult stage, the spiderlings lasted 137 days to attained maturity. Greater mortality was observed in the $3^{\text {rd }}$ and $4^{\text {th }}$ spiderling stages, decreasing thereafter and reaching zero in the $8^{\text {th }}$ spiderling stage.

Key words: life cycle, Marpissa bengalensis, Araneae.

Ciclo biológico, sobrevivência e expectativa de vida da aranha de folhagem (Marpissa bengalensis) em pomar cítros

RESUMO: Os estádios de desenvolvimento pós-embrionário de Marpissa bengalensis (Araneae; Salticidac), a segunda espécie predatória mais abundante no pomar citrico, foram coletadas no pomar experimental de frutas do Departamento de Horticultura, localizado no campus da Universidade de Agricultura de Faisalabad, onde foram estudados. O ciclo de biológico foi estudado no laboratório, em que iniciou a partir de ovos coletados de fêmeas grávidas e soltas em cativeiro. O periodo de incubação variou de 5 -15 dias. a média de ovos incubados foram 23,8 ovos/casulo e a porcentagem de incubação em condições laboratoriais foi de 73,18\%. A duração média da fase imatura a foi de 7 dias. Uma duração geral, média do terceiro estádio da fase imatura, foi de 7,46 dias de todas as fases imaturas incubadas com 8 casulos. A partir do quarto estádio da fase imatura a duração média foi de 10,23 dias. No quinto estádio de imaturação, demorou uma média de 19,82 dias. O sexto e o sétimo estádios de imaturação duraram um total de 23,14 e 25,86 dias, respectivamente. Durante o oitavo estádio de imaturação a duração foi de 28,08 dias, sendo máxima. Em média, desde a incubação até o estádio adulto, o estádio de imaturação duraram 137 dias. A maior mortalidade foi observada nos terciro e quarto estádios de imaturação, diminuindo, a partir de então, e atingindo zero no oitavo estádio de imaturação.

Palavras-chave: ciclo biológico, Marpissa bengalensis, Araneae.

\section{INTRODUCTION}

Spiders possess the characteristics of predators that can contribute to densityindependent limitation of prey, including selfdamping, high levels of polyphagy and life cycles that are asynchronous to those of prey species. Hunting spider made up $85.5-91.7 \%$ of the spider fauna in peanut agro ecosystem. Spiders may play an important role in stabilizing or regulating insect's populations because they are one of the most numerous insectivores and exhibit a wide variety of lifestyles and foraging strategies (NYFFELER et al., 1994).

Spider (Arachnidae: Aranae) is a most abundant, diverse and ecologically important group in many cropping systems (HODGE, 1999; SUNDERLAND AND SAMU, 2000; TAHIR et al., 2012; Hitherto 112 families, 3924 genera and 44540 species of spiders are described in the 
world (PLATNICK, 2014). They live in a variety of habitat like forest, fields, foliage, ground, and even some may live amphibious life (BUKHARI et al., 2012).

They have great importance in reducing and even preventing outbreaks of insect pests in agricultural fields (SUNDERLAND et al., 1986). They are capable of limiting and equilibrating pest populations (NYFFELER, 1982; SUNDERLAND AND SAMU, 2000), because of their abundance and high predatory potential (Tahir and Butt, 2009), prey specialization, polyphagy, top-down effect, numerical and functional responses, and wasteful killing (MALONEY et al., 2003).

Although, the number of prey in the field fluctuate with season, time of day, microhabitat and foraging strategy (UETZ, 1991), but different spiders residing in the same field may exploit same resources (HODGE, 1999). Hunting and web-weavers are the two major clusters of spiders (UETZ 1991; NYFFELER 1982; UETZ et al., 1999) which are further divided into six to eight guilds (i.e., foliage runners, ground runners, stalkers, ambushers, sheet web weavers, wandering sheet weaver, orb weaver and space web builders) based on web use, web type and microhabitat (UETZ et al., 1999). Marpissa bengalensis is a leading species in crop growing areas of Pakistan. It is the true predator and constitutes a heterogeneous group in terms of their feeding strategies, size and activity patterns. Preliminary study on life cycle is essential for ecological work and is of significance importance to investigate the predatory potential of a species.

\section{MATERIALS AND METHODS}

\section{Field collection of Marpissa bengalensis}

This specie was collected from the experimental fruit garden of Horticulture department located at University of Agriculture, Faisalabad. Generally spiders were more commonly present at the curly mortal leaves of citrus plants. Marpissa bengalensis females with or without cocoone particularly were present inside the old curled leaves, males were present on fresh and middle aged leaves. Males and the females were captured by direct hand picking jarring method and were placed separately in the polythene bages and were brought to the laboratory. Males and females of Marpissa bengalensis were identified and recognized for the collection of same species in the field. Marpissa bengalensis was identified with the help of field handlens and their hiding places were traced.

\section{Laboratory experiment}

Gravid females with or without cocoon were captured from the foliage of citrus trees and kept for the study of their daily activity and other behaviors such as hatching, post hatching developmental stages as spiderlings, their clutch size, brood care survivorship and mortality rate at each developmental stages till the adulthood in the laboratory.

At first hatching all young ones remained inside the cocoon and after $2-3$ days they come out $\mathrm{o} f$ the cocoons and ride on their mother back for 5-6 days. At the end of the second spiderling stage, they leave their mother, shed off their skin and attached them to the cage roof, so being able to move freely. Now each spiderling was transferred to the ennumbered cages. Latter on small pres like aphid, Jassid, whiteflies, fruit flies and large prey like mosquitoes, house flies, honey bees, grasshopper were meshed and then given to these young ones for their survival and their molting was also observed till adult. Remaining preys were cleaned and removed daily to avoid fungal and bacterial attacks. Daily observation chart was dully filed in the laboratory for the record of different developmental stages.

\section{Statistical analysis}

The data observed was analyzed for survivorship, mortality and life expectancy at different stages up to $8^{\text {th }}$ instar.

The survivourship (Lx) shall be calculated as $\mathrm{Lx}=\underline{\mathrm{Nx}}$

$$
\text { No }
$$

Where $\mathrm{Nx}=$ number of individual which were alive in each stage.

No $=$ Total number of eggs which hatched.

Life expectanc (ex) shall be calculated as:

$\mathrm{Ex}=\underline{\mathrm{Tx}}$

$$
\text { Lx }
$$

Where $\mathrm{Tx}=$ total number of remainder days in the life of an individual that had reached at $\mathrm{X}$, stage

$\mathrm{Tx}=\sum_{m}^{x} \mathrm{Lx}$

$\mathrm{m}$, being the maximum age which was reached

\section{RESULTS AND DISCUSSION}

Eight Marpissa bengalensis females with cocoon were released in separate cages. An average incubation period range was recorded as 5-15 days. Hatching percentage was recorded as $73.18 \%$ (Table 1). No hatching took place in the cocoons without female. 
Table 1 - Hatching \% age of eggs from each cocoons of Marpissa bengalensis.

\begin{tabular}{|c|c|c|c|c|c|c|c|c|c|c|}
\hline No of cocoons & 1 & 2 & 3 & 4 & 5 & 6 & 7 & 8 & Total & Mean \pm SD \\
\hline Total eggs & 35 & 30 & 28 & 25 & 30 & 35 & 38 & 40 & 261 & $32.6 \pm 5.18$ \\
\hline Eggs Hatched & 28 & 25 & 20 & 18 & 15 & 20 & 30 & 35 & 191 & $23.87 \pm 6.97$ \\
\hline
\end{tabular}

The hatched spiderlings remained inside the cocoon where two moults took place and prelarva changed into spiderling. Similar findings have been reported by RUBY et al. (2012). ENDERS (1996) studied that Lycosid spiders have higher egg production. After emergence, the spiderlings climbed on mothers back and ride until they able to move independently. This period is known as brood care and female do not feed in this phase. FOELIX AND CHU-WANG (1973) reported that the mother accesses her offspring during hatching and spiderlings climb on her back.

All the spiderlings passed six developmental stages before reaching adulthood. An average duration for $3^{\text {rd }}$ spiderling stage was 7.46 days. For $4^{\text {th }}$ spiderling stage the duration increased to 10.23 days. In the $5^{\text {th }}$ spiderling stage, the spiderling spent an average of 19.82 days.

Similarly for sixth, seventh and eighth spiderling stage the average duration was $23.14,25.86$ and 28.08 respectively (Table 2 ). Greater mortality was observed in the $3 \mathrm{rd}$ and $4^{\text {th }}$ spiderling stages, decreasing thereafter and

Table 2 - Average duration (days) and range of life cycle of Marpissa bengalensis.

\begin{tabular}{lcc}
\hline Developmental stages & Range & $\begin{array}{c}\text { Average } \\
\text { duration (days) }\end{array}$ \\
\hline $3^{\text {rd }}$ spiderling stage & $5-10$ & 7.38 \\
$4^{\text {th }}$ spiderling stage & $7-16$ & 10.20 \\
$5^{\text {th }}$ spiderling stage & $15-25$ & 19.95 \\
$6^{\text {th }}$ spiderling stage & $18-30$ & 23 \\
$7^{\text {th }}$ spiderling stage & $22-30$ & 25.59 \\
$8^{\text {th }}$ spiderling stage & $25-31$ & 28.08 \\
\hline
\end{tabular}

reaching zero in the $8^{\text {th }}$ spiderling stage (Table 3 ). Mortality rate at $3^{\text {rd }}$ and $4^{\text {th }}$ stage spiderling was in accordance with MINERVINO (1993). Large body size decreased mortality which is attained by extending growth period (Clader, 1984). The average duration of maturity period for male was recorded as 112 days and ranged from 112- 120 whereas, for female it was 126 days ranging from 121- 134 (Table 2).

There are reports of low mortality rate by Hibana velox, Chiracanthium inclusum and Trachelas volutes on combination of natural diets (AMALIN et al., 2002). Similar trend of comparatively less mortality or in other words better survival rate was observed with combined natural diets. The presence of above discussed nutrients probably explains the higher percent survival and normal development of spiders on the combination diet and also proved that the experimental species is also a nectar feeder as reported by Taylor and Foster (1996).

In conclusion it is suggested that mass rearing of such important predatory species against serious crop pests could be employed.

Table 3 - Survivershiop (Lx) and life expectancy in different developmental stages of Marpissa bengalensis.

\begin{tabular}{lccc}
\hline Developmental stages & $\mathrm{N}$ & $\mathrm{Lx}$ & $\mathrm{ex}$ \\
\hline $3^{\text {rd }}$ spiderling stage & 137 & 0.72 & 3.15 \\
$4^{\text {th }}$ spiderling stage & 113 & 0.59 & 7.12 \\
$5^{\text {th }}$ spiderling stage & 94 & 0.49 & 8.70 \\
$6^{\text {th }}$ spiderling stage & 86 & 0.45 & 9.02 \\
$7^{\text {th }}$ spiderling stage & 78 & 0.41 & 11.25 \\
$8^{\text {th }}$ spiderling stage & 78 & 0.41 & 11.25 \\
\hline
\end{tabular}




\section{REFERENCES}

AMALIN, D.M. et al. Comparison of the survival of three species of sac spiders on natural and artificial diets. J. Arachnol. v.29 p.253-262, 2001.

BUKHARI, M. et al. Occurrence and distribution of araneid fauna trapped from cotton fields of district Faisalabad, Pakistan. World Appl. Sci. J. v.19 p.714-718, 2012.

CLADER, W.A. Size, function and life history. Harvard University Press, Cambridge. USA, 1984.

ENDERS, F. Clutch-size related to hunting manners of spider species. Ann. Ent. Soc. Ame. v.69, p.991-998, 1996.

Foelix, R.F. et al. The morphology of spider sensilla chemoreceptor. Tiss. Cells. v.5, p44, 1973.

HODGE, M.A. The implications of intraguild predation for the role of spiders in biological control. J. Arachnol. v.27, p.351-362, 1999.

Maloney, D. et al. Spider predation in agroecosystems: Can spiders effectively control pest population. MAFES Tech. Bull. v. 190, p.1-32, 2003.

MINERVINO, E. Life cycle of Misumenops pallid (Araneae: Thomisidae). Mem. Inst. Oswaldo. Cruz, v.88, p.49-52, 1993.

NYFFELER, M. Field studies on the ecological role of spiders as insect predators in agro-ecosystems (abandoned grasslands, meadows and cereal fields). Ph.D. thesis. Swiss Fed. Inst. Tech., Zurich, Switzerland, 1982.
NYFFELER, M., W. et al. How spiders make a living. Entomological Society of America, v.23, n.6, p.1357-1367, 1994.

PLATNICK, N. I. The world spider catalog, Version 14.0. American Museum of Natural History. 2014. <http:/research.amnh.org/ entomology/spiders/catalog/index.html>. doi: $10.5531 / \mathrm{db} .1 \mathrm{z} .0001$.

SUNDERLAND, K. et al. Effects of agricultural diversification on the abundance, distribution, and pest control potential of spiders: a review. Ent. Exp. Appl., v.95, p.1-13, 2000.

SUNDERLAND, K. D. et al. Field and laboratory studies on money spiders (Linyphiidae) as predators of cereal aphids. J. Appl. Ecol., v.23, p.433-447, 1986.

TAHIR, H. M. et al. Effects of different management practices and field margins on the abundance of ground spiders in rice ecosystems. Pakistan. J. Zool., v.41, p.85-93, 2009.

TAHIR, H. M. et al. Effect of tillage practice on the seasonal dynamics of ground spiders. Pakistan. J. Zool., v.44, p.884-887, 2012.

RUBY, T. et al. Survivorship of ground spider Pardosa oakleyi (gravely) under laboratory conditions on natural and artificial diets. Pak. J. Agri. Sci. v.49, n.4, p.451-454, 2012.

TAYLOR, R.M. et al. Spider nectarivory. Ame. Entomol., v.20, p.82-86, 1996

UETZ, G. W. Habitat structure and Spider foraging. In: McCoy, E.D. et al. Habitat structure; the physical Arrangements of objects in space. Chapman and Hall, London, p.325-348, 1991.

UETZ, G.W. et al. Guild structure of spiders in major crops. J. Arachnl., v.27, p.270- 280, 1999. 